\title{
DESAFIOS DO ENSINO DA ESCRITA ACADÊMICA: UMA PROPOSTA DE ABORDAGEM DO GÊNERO RESENHA EM CONTEXTO DE EDUCAÇÃO A DISTÂNCIA
}

\author{
Flávia Zanatta ${ }^{1}$ \\ Garine Andréa Keller ${ }^{2}$ \\ Juliana Thiesen Fuchs ${ }^{3}$
}

\begin{abstract}
Resumo: Este trabalho tem como objetivo apresentar uma proposta de abordagem do gênero textual/ discursivo resenha em contexto de educação a distância que envolve a interação, a diversidade de materiais e o uso de ferramentas tecnológicas. Partindo do entendimento de que a aprendizagem da escrita de um gênero textual/discursivo se dá por meio do contato com exemplares desse gênero, da leitura e análise desses exemplares e da constante revisão e reescrita, organizamos um conjunto de seis aulas para contemplar todas essas açóes. As atividades propostas nessas aulas consistiram em leitura e análise de resenhas, apropriação de estratégias para sua elaboração, especificidades da resenha de obra cultural e da resenha acadêmica, escrita, avaliaçáo do texto de um colega e reescrita de resenha, e sua materializaçáo contou com o uso de algumas ferramentas disponibilizadas na plataforma Moodle. O desempenho dos estudantes nas atividades de escrita acadêmica desenvolvidas em turmas dos semestres 2019A e 2019B no componente curricular Leitura e Produção de Textos, bem como suas autoavaliaçóes do processo de aprendizagem da resenha são indicativos da efetividade de nossa proposta de abordagem desse gênero.
\end{abstract}

Palavras-chave: Ensino da escrita acadêmica. Resenha. Educação a distância. Uso de ferramentas tecnológicas. Interação.

1 Mestre em Letras pelo PPGLetras da UFRGS e Doutoranda em Ensino pelo PPGEnsino da Univates. Docente do Instituto Federal de Educação, Ciência e Tecnologia do Rio Grande do Sul - IFRS Campus Vacaria. flavia.zanatta@vacaria.ifrs.edu.br

2 Mestre em Letras, Cultura e Regionalidade pela Universidade de Caxias do Sul/RS. Docente do Curso de Letras da Universidade do Vale do Taquari - Univates. gkeller@univates.br

3 Mestre em Linguística Aplicada pelo PPGLA da Universidade do Vale do Rio dos Sinos - Unisinos. Docente do Curso de Letras da Universidade do Vale do Taquari - Univates. jtfuchs@univates.br 


\title{
CHALLENGES OF TEACHING ACADEMIC WRITING: A PROPOSAL FOR AN APPROACH WITH THE GENRE REVIEW IN A DISTANCE EDUCATION CONTEXT
}

\begin{abstract}
This work aims to present a proposal to approach the textual/discursive genre review in the context of distance education that involves interaction, the diversity of materials and the use of technological tools. Based on the understanding that learning to write a textual/discourse genre occurs by having contact with examples of that genre, reading and analyzing these examples and constantly revising and rewriting them, we designed a set of six classes to contemplate all these actions. The activities proposed in these classes consisted of reading and analyzing reviews, appropriating strategies for their elaboration, specificities of the cultural work and academic review, writing, evaluation of a classmate's text and rewriting the review, and its materialization relied on the use of some tools available on Moodle. The performance of students in academic writing activities developed in classes during the first and second semesters of 2019 in the Reading and Text Production curricular component, as well as their self-assessments of the review learning process are indicative of the effectiveness of our approach proposed for working with this genre.
\end{abstract}

Keywords: Teaching academic writing. Review. Distance education. Use of technological tools. Interaction.

\section{Consideraçóes iniciais}

É consenso entre os estudiosos da linguagem que o ensino de língua portuguesa deve visar à qualificação da competência comunicativa dos falantes, isto é, sua capacidade, como usuários da língua, "de produzir e compreender textos adequados à produção de efeitos de sentido desejados em situaçôes específicas e concretas de interação comunicativa" (TRAVAGLIA, 2014, s.p.). Essa destreza no uso da língua materna pode ser alcançada por meio de um ensino que trabalhe a oralidade, a escrita, a leitura e a gramática com o propósito de "ampliar as competências comunicativo-oracionais dos alunos" (ANTUNES, 2003, p. 34). Entretanto, nem sempre essa é a tônica do ensino de língua portuguesa na educação básica, e o reflexo disso pode ser visto no ensino superior, que, além de exigir dos estudantes o emprego de habilidades básicas de leitura, escrita e expressão oral, apresenta demandas específicas quanto à competência comunicativa que dizem respeito à leitura e produção de gêneros textuais/discursivos ${ }^{4}$ que circulam apenas na esfera acadêmica e com os quais, pouco provavelmente, tiveram contato ao longo de sua formação escolar.

4 Neste trabalho, adotamos a perspectiva de Marcuschi (2008), que usa a expressão gênero textual, sem diferenciá-la da expressão gênero discursivo ou gênero do discurso (expressão original de Bakhtin), pois assume que essas expressóes podem ser usadas intercambiavelmente, uma vez que o discurso sempre está implicado em qualquer texto, sendo o gênero "uma ponte entre o discurso como uma atividade mais universal e o texto enquanto peça empírica particularizada e configurada numa determinada composição observável" (p. 84). De qualquer forma, optamos por usar a expressão "gênero textual/discursivo" para deixar mais explícita essa perspectiva. 
Há, conforme Machado (2004), uma recorrente falta de ensino sistemático de gêneros da esfera escolar e/ou científica, o que pode fazer com que os alunos, ao ingressarem no ensino superior, sejam cobrados por aquilo que nunca lhes foi ensinado e precisem aprender por conta própria, intuitivamente, a lidar com certos gêneros textuais/discursivos. Segundo a autora, existe a ideia de uma capacidade geral para a escrita, que permitiria escrever bem qualquer espécie de texto. Mas estudos na área, como os de Motta-Roth; Hendges (2010) - que pesquisam a escrita na universidade - e os de Street (2014) - que investiga os letramentos acadêmicos -, demonstram que isso não procede, já que a complexidade das características de cada gênero exige que sejam desenvolvidas capacidades que vão além de apenas organizar e usar adequadamente as normas gramaticais. Para Marinho (2010), por exemplo, a crença de que basta aprender e treinar certas estratégias textuais para obter um bom desempenho nas práticas de escrita produz uma visão simplista e errônea acerca de no que consiste o ato de escrever. Sendo, portanto, a escrita uma atividade bastante complexa, é essencial oportunizar aos estudantes eventos de letramento acadêmico ${ }^{5}$, a fim de que possam ir construindo os seus saberes acadêmicos/científicos e também saibam se posicionar e perceber que os textos são produtos culturais concebidos para determinado fim (FISCHER, 2010).

Tal concepção pressupóe que o trabalho com a leitura e, principalmente, com a escrita na universidade deve estar calcado no dialogismo e na interação. Isso porque, de acordo com Bakhtin (2000), todos os enunciados são, independentemente de sua dimensão, dialógicos, ou seja, são perpassados pela palavra do outro. Há a incorporação do discurso do outro pelo enunciador e, ao ser dito, o enunciado espera uma resposta, de modo que, em cada interaçáo, valemo-nos de dizeres em resposta ao que já foi dito por outrem. Portanto, pensar a linguagem a partir de uma perspectiva bakhtiniana, dialógica de uso de linguagem, é pensar em enunciados sociais, culturais, concretos, os quais servem para comunicar, por meio da língua/ linguagem, uma apreciação, uma significação a respeito do mundo, das coisas, das pessoas e de outros ditos.

Porém, nem sempre a teoria e a prática se aliam para que o dialogismo e a interaçáo ocorram, e no ensino a distância, uma perspectiva de "ensinoaprendizagem interacionista é ainda mais complexa [...], uma vez que as interaçóes face-a-face entre os sujeitos são restritas" (CAZAROTO, 2009, p. 1258). Cabe destacar ainda que, nessa modalidade, "o ensino-aprendizagem se dá mais na relação material didático-aluno, elemento norteador do estudo a distância" (ibidem), e por isso é preciso empreender discussóes sobre a produçáo de materiais para $\mathrm{EaD}$, de modo a promover uma construção do conhecimento a partir da interação dialógica entre os sujeitos envolvidos, cada um participando ativamente do processo de ensino-aprendizagem. E para tal, é preciso ter claro que "um processo de ensino-

5 Neste trabalho, adotamos a perspectiva dos Novos Estudos do Letramento (STREET, 2014), que entendem a leitura e a escrita como práticas sociais situadas e estão vinculados à ruptura da visão de leitura e escrita como ações descontextualizadas que envolvem um conjunto de habilidades cognitivas individuais. 
aprendizagem em consonância com esta abordagem concebe o professor e o aluno numa constante interação, propiciada pela linguagem" (CAZAROTO, 2009, p. 1257).

As circunstâncias acima descritas se somam às "constantes queixas de professores universitários (e dos próprios alunos) de que os alunos têm dificuldade na leitura e na produção de textos acadêmicos", o que nos sinaliza "a necessidade de transformar essas queixas em propostas de ensino e de pesquisa" (MARINHO, 2010 , p. 364). Isso vem inquietando muitos professores e pesquisadores e tem levado diversas instituiçóes de ensino superior a inserir na matriz curricular dos seus cursos de graduação um ou mais componentes curriculares que promovam o aprimoramento dos conhecimentos linguísticos dos estudantes, bem como seu letramento acadêmico.

$\mathrm{Na}$ Universidade do Vale do Taquari - Univates, o componente Leitura e Produção de Textos integra a grade curricular dos cursos de graduaçáo desde 2012, sendo ofertado nas modalidades presencial, semipresencial e $\mathrm{EaD}^{6}$. Tal ação surgiu da observância de que era preciso abordar com os alunos, logo nos primeiros semestres da graduação, questôes que envolvem o texto em suas múltiplas formas e funções, com ênfase em habilidades e gêneros necessários ao longo de sua formação - escrita através de paráfrase, organização de parágrafo, resumo, resenha -, visto que muitos encontram dificuldades na leitura e escrita de gêneros acadêmicos que serão utilizados ao longo de todo o curso.

Há vários desafios nesse processo: a formação escolar bastante variada dos calouros, o que gera turmas, em geral, bem heterogêneas com relação aos conhecimentos prévios de língua portuguesa em diferentes níveis; a variedade quanto a curso e faixa etária; e, por fim, dois aspectos característicos do ensino a distância: a falta de contato presencial entre professor e estudante para conversarem sobre as produçóes, observando em conjunto o que precisa ser modificado para qualificar o texto, e a dificuldade de promover a interação, já que as atividades acabam sendo, em sua grande maioria, individuais, em função dos obstáculos que os alunos relatam encontrar para realizar tarefas em grupo quando não há um vínculo presencial entre os colegas.

É com base nesse cenário que, desde sua oferta inicial, o componente Leitura e Produção de Textos é organizado de forma dialógica e interativa, o que se intensificou a partir de 2016, quando o grupo de professoras da Univates que atuam na modalidade semipresencial passou a desenhar uma organização para buscar cada vez mais o dialogismo e a interação no trabalho com a língua portuguesa e o letramento acadêmico. Entáo, entendendo que a aprendizagem da escrita de um

6 As modalidades presencial e semipresencial contemplam $80 \mathrm{~h}$ e integram a grade curricular dos cursos presenciais. No formato semipresencial, dos dezoito encontros previstos no semestre, há quatro presenciais. Já na modalidade $\mathrm{EaD}$, o componente, que também tem carga horária de $80 \mathrm{~h}$, integra a grade curricular dos cursos ofertados totalmente a distância, com periodicidade trimestral. 
gênero textual/discursivo se dá por meio do contato com exemplares desse gênero, da leitura e análise desses textos e da constante revisão e reescrita, arquitetamos um percurso de aprendizagem que contemple todas essas açóes nos processos de ensino e de aprendizagem.

Neste texto, será apresentado o percurso elaborado para trabalhar o gênero resenha nas turmas de Leitura e Produção de Textos dos semestres 2019A e 2019B da Univates na modalidade semipresencial. Para isso, primeiramente apresentamos um panorama do componente curricular ofertado nessa modalidade; em seguida, a sequência de seis aulas destinadas à abordagem do gênero resenha; por fim, uma apreciação dos resultados da proposta desenvolvida, tanto na perspectiva das docentes quanto na dos discentes.

\section{A organizaçáo geral do componente Leitura e Produçáo de Textos na modalidade semipresencial para os semestres 2019A e 2019B}

A organização do componente Leitura e Produção de Textos leva em conta a heterogeneidade das turmas e as demandas do contexto universitário e busca promover um espaço em que os estudantes possam se inserir nas práticas de leitura e escrita dos gêneros acadêmicos. Sendo assim, são desenvolvidos, ao longo do semestre, três eixos: leitura, escrita e oralidade. Para dar conta de sua ementa, a qual prevê o estudo do texto em suas múltiplas formas e funçôes, com ênfase no texto acadêmico, e tendo em vista as demandas mais comuns na academia em termos de produção escrita e oral, definiu-se trabalhar com gêneros textuais/discursivos que levem ao aprimoramento das habilidades de leitura, compreensão, interpretação, escrita e posicionamento crítico, tais como o resumo e a resenha.

Ao longo do semestre, são abordados no componente tanto aspectos gramaticais quanto organizacionais do resumo e da resenha. Contudo, dá-se ênfase aos aspectos discursivos (para que são escritos, em que circunstância, quem é seu destinatário), dado que as dificuldades concernentes ao desempenho linguístico nessa sorte de texto não são resolvidas apenas através do conhecimento de regras gramaticais e de características próprias dos gêneros acadêmicos.

A relevância de dar destaque aos aspectos discursivos fica evidenciada na escrita de resumos e resenhas, que costumam ser gêneros bastante utilizados na academia como forma de avaliação por exigirem do estudante compreensão leitora, poder de síntese, emprego da paráfrase e do discurso citado e, no caso específico da resenha, a capacidade de se posicionar como alguém que tem algo a dizer a fim de convencer/persuadir o leitor. Assim, deve haver um esforço por parte do professor no sentido de levar o aluno à compreensão e ao domínio dessas práticas de escrita, $\mathrm{o}$ que implica fazer uso de diferentes ferramentas e estratégias de ensino.

Como já mencionado, todas as aulas desse componente na modalidade semipresencial são planejadas em conjunto entre as professoras que o ministram, as quais, anualmente, o reestruturam a partir de um tema norteador. Este determina a seleção dos textos que serão trabalhados nos blocos destinados a questóes relacionadas 
à compreensão leitora, oralidade e produçáo escrita. Geralmente são definidos três textos de gêneros diferentes, mas com temática afim, para explorar esses eixos da linguagem. A temática ainda pauta a escolha dos textos que serão disponibilizados para a escrita de resumo e resenha. No ano de 2019, o tema escolhido para permear os textos foi a oposiçáo senso comum versus ciência, ou seja, a tendência cada vez maior de as pessoas acreditarem naquilo com que já concordam (crenças não científicas ou pseudocientíficas) em vez de se abrirem para as explicaçôes científicas.

As cinco primeiras aulas do semestre formam um bloco no qual são exploradas estratégias de leitura, focando na qualificação da compreensão leitora. A sexta e a sétima aulas exploram a oralidade a partir de uma atividade em que os estudantes devem gravar um vídeo discutindo o tema proposto. A partir da oitava aula o foco está na escrita, e ao longo das dez últimas aulas são exploradas questôes sobre os gêneros resumo e resenha a partir de atividades práticas que promovem o autoestudo e a pesquisa e culminam na escrita de resumo e de resenha de obra cultural e de obra acadêmica.

Nosso propósito no planejamento do componente Leitura e Produção de Textos na modalidade semipresencial é promover a construção do conhecimento a partir da interação dialógica entre os sujeitos envolvidos, cada um participando ativamente dos processos de ensino e de aprendizagem, explorando ao máximo as possibilidades de uso das ferramentas disponíveis na plataforma Moodle, que é o ambiente virtual utilizado nos componentes semipresenciais e EAD na Univates, como ficará evidenciado a seguir.

\section{Descrição da proposta de abordagem do gênero resenha}

Entre as alternativas pensadas para abordar o gênero resenha no ensino semipresencial, adotamos um percurso que envolve conhecer o gênero, analisá-lo e, posteriormente, produzi-lo. As etapas consistem em leitura e análise de resenhas, apropriação de estratégias para sua elaboração, especificidades da resenha de obra cultural e da resenha acadêmica, escrita, avaliaçáo do texto de um colega e reescrita de resenha. Para materializar esse percurso, valemo-nos de algumas ferramentas disponibilizadas na plataforma Moodle, dentre as quais destacamos: Fórum, Laboratório de Avaliação, Lição, Questionário e Tarefa.

A seguir, descrevemos cada uma das seis aulas destinadas ao estudo do gênero resenha, detalhando os propósitos pedagógicos pretendidos e como se deu sua organizaçáo.

\subsection{Aula 1 - Resenha: o que é e como se faz?}

O intuito da primeira aula destinada ao estudo da resenha é fazer com que os alunos conheçam as características desse gênero. Organizadas em duas etapas, as atividades consistem em uma leitura guiada de duas resenhas - de um filme, em formato de texto oral (vídeo), e de um livro, em formato de texto escrito -, 
utilizando a ferramenta Questionário, e na seleção de resenha de obra cultural para ser compartilhada no recurso Fórum.

Como material didático, é disponibilizada uma breve apresentação de slides sobre as características gerais do gênero resenha, com análise de algumas resenhas de obra cultural (filme, livro, show etc.) e destaque para as açóes constitutivas do gênero: apresentar, descrever, avaliar e recomendar a obra. Assim, os alunos podem ter uma base para responder às questôes, cujo feedback também acaba funcionando como material didático, pois ressalta a observação das características do gênero.

Para o cumprimento da primeira etapa, os estudantes são convidados a ler as resenhas e responder a um questionário que contempla tanto questôes de conteúdo quanto de estrutura dos textos lidos e cujo objetivo é levá-los a perceber que a resenha se trata de um gênero que tem como finalidade convencer o leitor a tomar ou não contato com a obra resenhada. As respostas das questôes são dissertativas, e é apresentado, ao final do envio das questóes, um feedback, para que os alunos possam analisar suas respostas, conforme explicitado no quadro a seguir.

Quadro 1. Roteiro para análise de resenhas disponibilizado na ferramenta Questionário

\begin{tabular}{|l|l|}
\hline \multicolumn{1}{|c|}{$\begin{array}{c}\text { Questóes relativas ao conteúdo } \\
\text { dos textos }\end{array}$} & \multicolumn{1}{c|}{ Feedback } \\
\hline $\begin{array}{l}\text { (1) A resenha comenta criticamente } \\
\text { uma obra. A crítica feita à obra é } \\
\text { positiva ou negativa? }\end{array}$ & $\begin{array}{l}\text { (1) Observe que, nas duas resenhas, a ação de avaliar a obra } \\
\text { aparece desde o início até o final, deixando claro ao leitor, } \\
\text { por meio de vários elementos (qualificaçóes tanto da obra } \\
\text { em si quanto de todos os envolvidos em sua produçáo), se a } \\
\text { crítica é positiva ou negativa. }\end{array}$ \\
\hline $\begin{array}{l}\text { (2) Quais são os principais } \\
\text { argumentos que o(a) autor(a) da } \\
\text { resenha apresenta em defesa de seu } \\
\text { ponto de vista? }\end{array}$ & $\begin{array}{l}\text { (2) Observe que, nas duas resenhas, os autores já começam } \\
\text { argumentando, qualificando a obra resenhada para defender } \\
\text { seu ponto de vista em relaçáo à qualidade da obra. Vários } \\
\text { aspectos da obra sáo qualificados, desde o enredo da história } \\
\text { e a forma como ela é contada até a competência de quem a } \\
\text { produziu. Todas essas qualificaçóes podem ser consideradas } \\
\text { argumentos. }\end{array}$ \\
\hline $\begin{array}{l}\text { (3) O(a) autor(a) inicia a resenha } \\
\text { falando sobre si mesmo(a). Por que } \\
\text { ele(a) faz isso? Qual o efeito disso } \\
\text { para a argumentaçáo da resenha em } \\
\text { defesa de seu ponto de vista? }\end{array}$ & $\begin{array}{l}\text { (3) Observe que no vídeo, Isabela Boscov começa falando } \\
\text { de sua própria experiência em relaçáo aos filmes que } \\
\text { assiste, aproveitando para comparar com a experiência de } \\
\text { assistir Amor sem escalas. Da mesma forma, Filipe Larêdo } \\
\text { também inicia sua resenha narrando a "saga" de como foi } \\
\text { que conheceu o livro Barba ensopada de sangue. Náo é por } \\
\text { acaso que eles iniciam as resenhas falando sobre si mesmos. } \\
\text { Estrategicamente, os autores fazem isso para causar um efeito } \\
\text { no espectador/leitor: a sensaçáo de que a obra resenhada } \\
\text { é especial, diferente das outras, e que por isso vale a pena } \\
\text { conhecê-la. }\end{array}$ \\
\hline
\end{tabular}




\section{Questóes relativas ao conteúdo dos textos}

(4) Ao descrever a obra resenhada, o(a) autor(a) da resenha conta brevemente o enredo da história que a obra aborda. Você conseguiu compreender a história contada por meio do que é dito na resenha? Diga, em poucas palavras, qual é o enredo da história da obra resenhada.

(5) Em alguns trechos, a resenha fala sobre os responsáveis pela obra (o diretor, no caso do filme; o autor, no caso do livro). Por que o(a) autor(a) da resenha optou por falar sobre essas pessoas? Qual é o efeito desses comentários em relação à argumentação da resenha para a defesa do ponto de vista?

(6) Ao interagir com esta resenha, você conseguiu identificar todas as açóes que uma resenha deve desempenhar (apresentar, descrever, avaliar e recomendar a obra)?

(7) Agora, compare as duas resenhas, apontando o que elas têm em comum e em que elas diferem. Considere especialmente as seguintes questóes:

(a) As açóes da resenha (apresentar, descrever, avaliar e recomendar a obra) aparecem na mesma ordem nas duas resenhas?

(b) Alguma ação deixou de ser desempenhada em alguma das resenhas? Alguma ação foi predominante em relação às demais (por exemplo, o(a) autor(a) avaliou mais do que descreveu a obra)?

(c) Em sua opinião, por que os autores das resenhas optaram por organizá-las dessa forma?

\section{Feedback}

(4) Observe que, na resenha do livro, o resenhista ocupa apenas 3 parágrafos para contar o enredo da história. É uma descrição breve, mas suficiente para a compreensão do que acontece na história. $\mathrm{Na}$ resenha do filme, a resenhista conta a história do filme em 3 minutos (metade do vídeo), aproveitando os recursos de edição para mostrar cenas e trilha sonora do filme, o que ajuda o espectador a entrar no "clima" do filme resenhado

(5) Observe que, em uma resenha, todos os comentários sobre quem produziu a obra acabam servindo indiretamente para qualificar a obra, contribuindo para a defesa do ponto de vista do(a) resenhista sobre a qualidade da obra.

(6) Observe que todas as açôes aparecem nas duas resenhas. Nem todas as resenhas apresentam as açôes na mesma ordem.

(7) (a, b e c) Lembre-se de que, sempre que nos comunicamos, queremos causar algum efeito em nosso interlocutor, e isso se reflete nas escolhas que fazemos para organizar nosso texto. No caso das resenhas que estamos analisando, qual efeito os autores parecem querer causar no espectador/leitor ao organizar as resenhas dessa forma?

Fonte: Das autoras (2019).

A segunda etapa consiste em uma atividade interativa na ferramenta Fórum do ambiente virtual: os alunos são convidados a procurar resenhas de obra cultural em jornais, revistas, blogs, sites etc. e compartilhar com os colegas e a professora 
alguma que tenham considerado interessante, dizendo por que chamou sua atençáo e apontando elementos em comum entre a resenha compartilhada e as resenhas analisadas na primeira etapa da atividade.

\subsection{Aula 2 - Produção da resenha de obra literária}

A segunda aula destinada ao estudo da resenha objetiva a prática da escrita desse gênero. No intuito de levar os estudantes a aplicar os conhecimentos construídos na aula anterior, é proposta a produção de uma resenha de obra literária a ser compartilhada na ferramenta Fórum. $\mathrm{O}$ uso desse recurso se deve à intençáo de promover entre os estudantes a interação, já que, de forma simplificada, um é convidado a revisar a resenha do outro, sugerindo alteraçóes.

Também nesta aula a organização das atividades se dá em duas etapas, uma focando a escrita e a outra a revisão da resenha produzida pelos alunos. Para realizar a escrita, é disponibilizado, na ferramenta Pasta, um conjunto de treze contos, dentre os quais os estudantes devem escolher apenas um, e um roteiro de questóes para a leitura guiada do conto. Esse roteiro é organizado em dois conjuntos de questóes, um que enfatiza a sensibilizaçáo para a leitura do conto e outro que norteia a leitura com vistas à produção da resenha.

Quadro 2. Roteiro para leitura de texto literário, disponibilizado no formato arquivo de editor de texto

\section{Sensibilizaçáo para a leitura}

1) O conto é um texto literário. Dessa forma, NÃO é possível atribuir a ele uma intenção como as dos textos que vimos até agora em sala de aula (convencer, informar etc.). A intençáo do texto literário é provocar no leitor algum tipo de emoção. No caso específico do conto, que gravita em torno de um só conflito, a intenção é provocar no espírito do leitor uma impressão singular: pavor, ódio, indignaçãa etc.

Com base nisso, responda:

1a) Como você reagiu ao conto lido? Qual (ou quais) emoção (emoçóes) o conto despertou em você?

1b) Qual (ou quais) parte(s) do conto mexeu (mexeram) com você? Transcreva essa(s) parte(s) do texto.

1c) Por que essa(s) parte(s) mexeu (mexeram) com você?

2) O conto é uma narrativa. Ou seja, a história é contada por meio de uma situação inicial (apresentação dos personagens, do cenário etc.), uma complicação (conflito; modificação da situação inicial por meio de uma ação), um clímax (momento de maior intensidade do conflito, ponto alto de tensão da história) e um desfecho (encaminhamento para a situação final).

Com base nisso, responda:

2a) Em qual parte do conto lido você acha que está o clímax da história? Transcreva essa parte do texto.

2b) Por que você identificou o clímax da história nessa parte do conto? 


\begin{tabular}{|l|}
\hline \multicolumn{1}{|c|}{ Leitura guiada do conto como preparaçáo para a escrita da resenha } \\
\hline 3) Qual é o título do conto? Em que livro ele foi publicado? Você já conhecia esse conto (já havia \\
lido, já havia ouvido falar dele ou do livro)? \\
4) Qual é o nome do(a) autor(a) do conto? Você já conhecia esse(a) autor(a)? Já leu alguma outra \\
obra dele(a)? Quantas e quais são as obras mais importantes já publicadas por ele(a)? \\
5) Dados adicionais sobre a publicaçáo do conto: Qual é a editora? Trata-se de um conto traduzido \\
de outro idioma? Qual é o nome do(a) tradutor(a)? Em que ano o conto foi publicado? Trata-se de \\
uma obra conhecida? Já foi bem avaliada pela crítica? \\
6) Qual é o tema abordado na história do conto (traição, superação, assassinato, romance etc.)? Em \\
sua opinião, trata-se de um tema interessante e relevante, que merece ser retratado em um conto \\
literário? \\
7) Quantas páginas tem o conto? Em sua opinião, trata-se de um conto curto demais, comprido \\
demais ou na medida certa em relação à história contada? \\
8) Qual é o enredo da história contada? Quem são os personagens principais e o que acontece com \\
eles (qual é o acontecimento que dá origem à trama da história)? \\
9) Questôes de gosto particular (ao respondê-las com "sim" ou "não", você deve acrescentar os \\
motivos de sua resposta): Você gostou de ler o conto? Achou a história bem contada? O final foi \\
surpreendente? Você acha que a história deveria ter outro final? A linguagem utilizada no conto \\
fez a leitura fluir? Você se sentiu envolvido pela leitura? A leitura do conto fez você refletir sobre \\
alguma situaçáo já vivenciada por você (ou sobre pensamentos e sentimentos que você tenha)? \\
10) Você acha que o conto é bom e merece ser lido por outras pessoas? Para qual público você \\
indicaria a leitura desse conto (estudantes, jovens, público em geral etc.)?
\end{tabular}

Fonte: Das autoras (2019).

Após a escrita, as produçôes são postadas no fórum. Feita a postagem, os alunos têm acesso às resenhas produzidas pelos colegas, devendo escolher uma para ler e avaliar à luz de um conjunto de questóes destinado a auxiliar nesse processo de contribuir, de forma qualitativa, com o texto de um colega. Nessa avaliação, os alunos, apoiados também no material didático disponibilizado no Ambiente Virtual, identificam se o texto do colega contempla as etapas que compóem a resenha, ou seja, se apresenta, descreve, avalia e recomenda o conto, bem como observam se o texto do colega cumpre o propósito de uma resenha (convence o leitor a querer ou não ler a obra resenhada). 
Quadro 3. Roteiro para avaliaçáo do texto escrito pelo colega, disponibilizado no formato arquivo de editor de texto

\section{Roteiro de questóes para a avaliaçáo da resenha do colega}

A resenha que você vai ler foi escrita com o objetivo de convencê-lo(a) a querer (ou a não querer) ler o conto apresentado por seu colega. O texto deveria apresentar, descrever, avaliar e recomendar o conto.

Leia a resenha do seu colega e avalie-a, respondendo às seguintes questóes:

1) É possível identificar a apresentaçáo do conto resenhado? Seu colega mencionou ao menos o título do conto e o nome do autor no início do texto?

2) É possível identificar a descrição do conto resenhado? Seu colega contou brevemente o enredo da história do conto?

3) A descrição do conto apresenta elementos suficientes para que você conheça a história narrada?

4) É possível identificar a avaliação do conto resenhado? Seu colega apresentou os pontos positivos (ou negativos) do conto?

5) É possível identificar, explícita ou implicitamente, a recomendação do conto resenhado? Fica claro se o seu colega quer que você leia (ou que você não leia) o conto?

6) A resenha está escrita de forma interessante, procurando cativar o leitor?

7) Você diria que o texto atinge o objetivo pretendido? O texto convenceu você a querer (ou a não querer) ler o conto apresentado pelo seu colega?

8) Você diria que o texto que você leu é uma resenha?

9) Você gostaria de fazer algum comentário, observação ou sugestão para o colega sobre o seu texto?

Fonte: Das autoras (2019).

\subsection{Aula 3 - Resenha acadêmica: o que é e como se faz?}

$\mathrm{Na}$ terceira aula, o intuito é que os alunos aprofundem seus conhecimentos sobre a estruturação do gênero resenha e tenham contato com as especificidades da resenha acadêmica. Além disso, almeja-se que os discentes conheçam algumas estratégias para organizar esse texto. Para tanto, as atividades dessa aula também são organizadas em duas etapas: leitura e análise de duas resenhas acadêmicas por meio da ferramenta Questionário e seleçáo de resenha acadêmica da área de formaçáo do estudante para ser compartilhada por meio da ferramenta Fórum.

Entre os materiais didáticos disponíveis nesta aula, estáo tutoriais de como pesquisar resenhas acadêmicas em bases de dados e uma apresentação, na ferramenta Livro do ambiente virtual, explicando as características desses textos.

$\mathrm{Na}$ primeira etapa, os alunos são instigados a identificar diferenças e semelhanças entre as resenhas lidas a partir do questionário abaixo, cujo feedback é disponibilizado imediatamente após o envio das respostas. 
Quadro 4. Roteiro para análise de resenha acadêmica, disponibilizado através da ferramenta Questionário

\begin{tabular}{|c|c|}
\hline Questáo & Feedback \\
\hline (1) A resenha apresenta um título? Qual? & $\begin{array}{l}\text { Observe que apenas uma das resenhas apresenta } \\
\text { um título próprio. A outra não tem título, exibindo } \\
\text { apenas a ficha bibliográfica do livro resenhado. } \\
\text { É opcional colocar título próprio em uma resenha. } \\
\text { Muitos resenhistas optam por essa estratégia, o que } \\
\text { faz com que sua resenha tenha potencial para chamar } \\
\text { mais a atenção do leitor. Porém, alguns periódicos } \\
\text { (revistas) acadêmicos adotam a falta de título } \\
\text { próprio como um padrão de formatação das resenhas } \\
\text { publicadas ali. }\end{array}$ \\
\hline (2) Quem escreveu a resenha? & $\begin{array}{l}\text { Nas duas resenhas, essa informaçáo aparece } \\
\text { imediatamente antes do início do texto da resenha. }\end{array}$ \\
\hline $\begin{array}{l}\text { (3) Qual é a obra resenhada? Como ela } \\
\text { é identificada antes do início do texto da } \\
\text { resenha (por meio de ficha bibliográfica, } \\
\text { imagem da capa etc.)? }\end{array}$ & $\begin{array}{l}\text { Observe que ambas as resenhas exibem a imagem } \\
\text { da capa do livro, o que ajuda a identificar a obra e } \\
\text { permite que o leitor a visualize. Além disso, as duas } \\
\text { resenhas trazem uma lista dos dados de identificação } \\
\text { da obra, uma abaixo do texto, em forma de itens, e } \\
\text { outra acima do texto, em forma de ficha bibliográfica. }\end{array}$ \\
\hline $\begin{array}{l}\text { (4) Como a resenha desempenha a ação de } \\
\text { apresentar a obra? } \mathrm{O}(\mathrm{s}) \text { autor(es) da resenha } \\
\text { discorre }(\mathrm{m}) \text { sobre o assunto da obra para } \\
\text { apresentá-la? A resenha fala sobre o }(\mathrm{s}) \\
\text { autor(es) da obra resenhada, indicando sua } \\
\text { experiência e suas qualidades? }\end{array}$ & $\begin{array}{l}\text { Observe que ambas as resenhas iniciam com a } \\
\text { mesma estratégia: discorrer sobre o tema para cativar } \\
\text { o leitor e mostrar a ele sua relevância, para a partir } \\
\text { disso apresentar a obra, mostrando que é justamente } \\
\text { daquele tema que ela vai tratar. } \\
\text { Porém, apenas uma das resenhas discorre sobre o } \\
\text { autor da obra, qualificando-o e evidenciando sua } \\
\text { competência para escrever a obra. Na outra resenha, } \\
\text { a resenhista não se preocupou com essa estratégia, o } \\
\text { que prejudicou a plena apresentaçáo da obra. }\end{array}$ \\
\hline $\begin{array}{l}\text { (5) Como a resenha descreve a obra } \\
\text { resenhada? Há trechos de descriçáo física } \\
\text { (quantidade de partes e capítulos, título de } \\
\text { cada parte etc.)? } \mathrm{O}(\mathrm{s}) \text { autor(es) descrevem } \\
\text { bem o conteúdo da obra? É possível } \\
\text { compreender do que a obra trata? }\end{array}$ & $\begin{array}{l}\text { Observe que ambas as resenhas iniciam a descrição } \\
\text { da obra falando de suas características físicas (número } \\
\text { de seçóes e capítulos em que é organizada), o que } \\
\text { permite que o leitor visualize a obra. Em seguida, } \\
\text { os resenhistas explicam o que é dito em cada uma } \\
\text { das partes da obra, dando conta de sua sumarização } \\
\text { completa. Essa descriçáo é mais minuciosa em uma } \\
\text { das resenhas. }\end{array}$ \\
\hline $\begin{array}{l}\text { (6) Você diria que a resenha cita } \\
\text { adequadamente o que é dito na obra } \\
\text { resenhada? Fica claro quais sáo as ideias } \\
\text { do(s) autor(es) da obra e quais são as } \\
\text { ideias do(s) autor(es) da resenha? Em } \\
\text { alguma parte da resenha essas "vozes" se } \\
\text { confundiram? }\end{array}$ & $\begin{array}{l}\text { Observe que, em ambas as resenhas, há frases que náo } \\
\text { indicam explicitamente (por meio de verbos de dizer } \\
\text { ou conectores de conformidade) a autoria das ideias. } \\
\text { Nessas frases, você diria que fica claro de quem são as } \\
\text { ideias? Da resenhista ou do(s) autor(es) da obra? }\end{array}$ \\
\hline
\end{tabular}




\begin{tabular}{|l|l|}
\hline \multicolumn{1}{|c|}{ Questáo } & \multicolumn{1}{|c|}{ Feedback } \\
\hline $\begin{array}{l}\text { (7) Como a resenha avalia a obra? Quais } \\
\text { aspectos da obra sáo avaliados? Essa } \\
\text { avaliaçáo aparece ao longo da resenha ou } \\
\text { concentrada em algum trecho? }\end{array}$ & $\begin{array}{l}\text { Observe que, em uma das resenhas, a avaliação está } \\
\text { localizada em um parágrafo específico, concentrando } \\
\text { ali a qualificação da obra. Na outra resenha, a } \\
\text { avaliação náo aparece táo explicitamente. }\end{array}$ \\
\hline $\begin{array}{l}\text { (8) A resenha recomenda a leitura da da } \\
\text { obra? Essa recomendaçáo é explícita? A } \\
\text { obra é recomendada para algum público } \\
\text { específico? }\end{array}$ & $\begin{array}{l}\text { Em ambas as resenhas, a recomendação da obra } \\
\text { aparece explicitamente no último parágrafo, } \\
\text { especificando o público ao qual a obra é indicada e } \\
\text { explicando por que esse público pode se beneficiar da } \\
\text { leitura da obra. }\end{array}$ \\
\hline $\begin{array}{l}\text { (9) Após comparar as resenhas, responda: } \\
\text { você diria que uma das resenhas está mais } \\
\text { bem escrita? Qual? Justifique sua resposta. }\end{array}$ & Resposta pessoal. \\
\hline
\end{tabular}

Fonte: Das autoras (2019).

$\mathrm{Na}$ segunda etapa da aula, os alunos devem buscar, em bases de dados e periódicos acadêmicos, resenhas relativas à sua área de formação ${ }^{7}$. Essas resenhas devem ser compartilhadas em um Fórum, para que colegas e professoras possam acessá-las. A ideia é que os alunos justifiquem por que essas resenhas chamaram sua atenção e que encontrem pontos em comum e diferenças entre esses textos e aqueles disponibilizados no ambiente e analisados anteriormente.

\subsection{Aula 4 - Produçáo de resenha acadêmica (etapa da escrita)}

$\mathrm{Na}$ quarta aula da sequência, o objetivo é que os estudantes pratiquem a escrita de uma resenha acadêmica com base em tudo o que estudaram a respeito da resenha. Como se trata de um gênero que, provavelmente, será bastante solicitado aos alunos ao longo de sua trajetória na universidade, a resenha acadêmica exige um processo de produção mais detalhado. Portanto, a escrita é proposta em três aulas: uma para a elaboraçáo da primeira versáo do texto, outra para a avaliaçáo da resenha de um colega e a última para a reescrita com vistas à versão final.

A escrita se origina a partir da escolha, por parte dos estudantes, de um dos textos disponibilizados pelas professoras, os quais compartilham a temática adotada para o semestre, de modo a fornecer mais subsídios aos alunos no momento de constituírem a argumentação que sustentará sua apreciação do texto resenhado.

São disponibilizadas, ainda, orientações que envolvem a situação de comunicação, a localização do texto na biblioteca virtual e informaçóes adicionais que podem auxiliar o aluno na escrita da resenha:

7 Essa dinâmica de colocar o estudante em contato com resenhas autênticas veiculadas em seu contexto original de publicaçáo se mostra bastante interessante no alcance do propósito de promover o letramento acadêmico. 
Nas aulas passadas, você conheceu e praticou a escrita do gênero resenha, bem como explorou as características de uma vertente específica desse gênero: a resenha acadêmica. Agora você vai praticar a escrita desse gênero específico conforme a proposta a seguir.

Imagine que você, após ter cursado a disciplina Leitura e Produção de Textos, foi convidado a escrever uma resenha acadêmica com a finalidade de contar aos futuros estudantes da disciplina como foi a experiência de ler um dos capítulos de livro propostos na disciplina e como essa leitura pode contribuir para sua trajetória acadêmica.

Para tanto, primeiramente escolha e leia UM dos capítulos de livro da lista a seguir:

- capítulo Estresse, escrito por Ivan Izquierdo, publicado no livro Tempo de Viver (informaçóes bibliográficas aqui);

- capítulo Para que estudar gramática?, escrito por Mário A. Perini, publicado no livro Gramática descritiva do português brasileiro (informaçóes bibliográficas no próprio livro digital);

- capítulo A evoluçáo do certo e do errado, escrito por Paulo Pedrosa (Pirula) e Reinaldo José Lopes, publicado no livro Darwin sem frescura: como a ciência evolutiva ajuda a explicar algumas polêmicas da atualidade (informaçôes bibliográficas na própria cópia do capítulo);

- capítulo A violência neuronal, escrito por Byung-Chul Han, publicado no livro Sociedade do Cansaço (informaçôes bibliográficas no próprio livro digital);

Atente para o fato de que você fará a resenha de um capítulo que integra um livro, e náo uma resenha do livro todo; isso deve ficar evidente na resenha. No entanto, observe que outras partes do livro podem contribuir para a escrita da resenha: por exemplo, a ficha catalográfica contém a referência bibliográfica completa do livro, o sumário contém informaçôes sobre como ele se organiza, há páginas contendo informaçôes sobre o(s) autor(es) etc.

Após ler o capítulo escolhido e observar os demais elementos relevantes do livro em que está inserido, elabore sua resenha acadêmica levando em consideração tudo o que estudamos sobre esse gênero:

- seu objetivo será convencer ou persuadir o leitor (outros acadêmicos como você, que ainda vão cursar essa disciplina) de que vale a pena a leitura do capítulo;

- para atingir esse objetivo, sua resenha deverá desempenhar as seguintes açóes:

- Apresentar o capítulo;

- Descrever o capítulo;

- Avaliar o capítulo;

- Recomendar o capítulo.

Lembre-se de que seu leitor NÁO leu o capítulo que você está resenhando; portanto, escreva sua resenha tendo em mente que é por meio dela que o leitor saberá do que se trata o capítulo e se vale a pena sua leitura.

Observe que, para a produção desta resenha acadêmica, você precisará mobilizar todas as habilidades aprendidas ao longo de nossas aulas (estratégias de leitura, coesão e coerência, paráfrase, influência sobre o interlocutor, sumarizaçáo, discurso citado, açóes da resenha acadêmica). Portanto, esta produção será a oportunidade de você mostrar o que aprendeu - e aprimorar esse aprendizado, por meio das etapas a serem desempenhadas nas próximas aulas!

Fonte: Das autoras (2019).

A submissão da primeira versão aos colegas foi pensada para que a produção textual desperte nos estudantes a motivação de se colocarem como autores que têm algo a dizer para um interlocutor específico em uma determinada situaçáo de comunicação. Tal versão deve ser postada na ferramenta Laboratório de Avaliação, que, diferentemente da ferramenta Fórum, permite que o estudante tenha acesso e avalie o texto de um único colega, de forma anônima. Os alunos são orientados sobre o funcionamento da ferramenta, que, após determinado prazo estipulado, sorteia entre os estudantes quem avaliará cada texto. Por isso, todos são alertados da necessidade da observância do prazo para postagem da tarefa, porque, após seu 
término, não é mais possível participar do sorteio e receber uma resenha para avaliar, além de não ter a sua resenha avaliada.

Essa ferramenta se mostrou fundamental no cumprimento de nosso propósito de promover o dialogismo e a interação, tendo em vista que possibilita o emprego da estratégia de ensino e de aprendizagem Avaliação por pares, um método de ensino interativo que, a partir de discussôes sobre questôes conceituais mediadas pelo professor, almeja modificar o comportamento do aluno, fazendo com que todos os discentes se envolvam com o conteúdo abordado por meio de questionamentos estruturados, promovendo o aprendizado colaborativo (MAZUR, 2015).

Logo, nosso objetivo ao propor o uso dessa ferramenta é justamente minimizar a falta de interação entre os alunos e, ao mesmo tempo, tornar a produçáo mais significativa para o estudante, já que o texto será lido não apenas pelo professor, mas também por um colega.

\subsection{Aula 5 - Produçáo de resenha acadêmica (etapa da avaliaçáo)}

A quinta aula é o momento de cada estudante avaliar o texto de um colega na ferramenta Laboratório de Avaliação, a partir de um roteiro destinado a fazer o aluno observar características essenciais do gênero, de modo a garantir os propósitos comunicativos deste. Esse olhar guiado, além de contribuir para a melhoria do texto do colega, auxilia sobremaneira o avaliador no momento em que ele retorna à própria resenha para qualificá-la.

No quadro a seguir, sáo descritos os aspectos que os alunos devem avaliar nos textos dos colegas. Em cada item, o avaliador tem espaço para uma resposta dissertativa, inclusive devendo destacar trechos do texto do colega que comprovem sua avaliação.

Quadro 6. Roteiro para avaliação da resenha escrita por um colega, disponibilizado na ferramenta Laboratório de Avaliaçáo

\begin{tabular}{|l|l|}
\hline \multicolumn{1}{|c|}{ Questáo } & \multicolumn{1}{c|}{ Descriçáo } \\
\hline $\begin{array}{l}\text { A resenha está } \\
\text { adequada ao } \\
\text { interlocutor? }\end{array}$ & $\begin{array}{l}\text { Deve-se ter em mente que o interlocutor de uma resenha não leu o texto original } \\
\text { ainda. A resenha do colega foi escrita levando em consideração um leitor que } \\
\text { não leu a obra original? }\end{array}$ \\
\hline $\begin{array}{l}\text { Quanto à } \\
\text { apresentaçáo } \\
\text { da obra }\end{array}$ & $\begin{array}{l}\text { A resenha inicia de forma interessante, captando a atenção do leitor (com um } \\
\text { título chamativo e uma primeira frase cativante)? Transcreva o(s) trecho(s) em } \\
\text { que isso se evidencia. }\end{array}$ \\
\cline { 2 - 2 } & $\begin{array}{l}\text { São apresentados os dados da obra (título, autor, dados de publicação)? Esses } \\
\text { dados estão apresentados adequadamente (em forma de texto, não em forma de } \\
\text { lista)? Transcreva o(s) trecho(s) em que esses dados aparecem, comentando se } \\
\text { essa apresentação parece adequada. }\end{array}$ \\
\cline { 2 - 2 } & $\begin{array}{l}\text { São apresentados dados sobre o(a) autor(a) da obra (formação, profissão, outras } \\
\text { publicaçóes etc.)? Esses dados estáo apresentados adequadamente (em forma } \\
\text { de texto, náo em forma de lista)? Transcreva o(s) trecho(s) em que esses dados } \\
\text { aparecem, comentando eles estão apresentados de forma adequada. }\end{array}$ \\
\hline
\end{tabular}




\begin{tabular}{|c|c|}
\hline Questáo & Descrição \\
\hline \multirow[t]{3}{*}{$\begin{array}{l}\text { Quanto à } \\
\text { descriçáo da } \\
\text { obra }\end{array}$} & $\begin{array}{l}\text { O colega sumarizou a obra? Demonstrou compreensão das ideias da obra? } \\
\text { Transcreva o(s) trecho(s) em que o colega descreveu a obra, comentando se essa } \\
\text { descrição parece adequada. }\end{array}$ \\
\hline & $\begin{array}{l}\text { O(a) autor(a) da obra é citado(a) durante a resenha? Você considera que fica } \\
\text { claro quando a ideia é do(a) autor(a) da obra e quando a ideia é do resenhador? } \\
\text { Transcreva o(s) trecho(s) em que isso se evidencia. }\end{array}$ \\
\hline & $\begin{array}{l}\text { Foram utilizados os verbos de dizer e os conectores de conformidade apropriados } \\
\text { para apresentar as ideias do(a) autor(a) da obra? Transcreva o(s) trecho(s) em } \\
\text { que isso se evidencia. }\end{array}$ \\
\hline \multirow{2}{*}{$\begin{array}{l}\text { Quanto à } \\
\text { avaliaçáo da } \\
\text { obra }\end{array}$} & $\begin{array}{l}\text { Quais argumentos foram utilizados por seu colega para avaliar a obra resenhada? } \\
\text { Transcreva o }(s) \text { trecho(s) em que esses argumentos aparecem. }\end{array}$ \\
\hline & $\begin{array}{l}\text { A avaliação feita pelo colega é adequada (avaliou a obra, náo seu tema)? } \\
\text { Mencionou os pontos fortes da obra (e relativizou seus eventuais pontos fracos)? } \\
\text { Transcreva o(s) trecho(s) em que isso se evidencia. }\end{array}$ \\
\hline $\begin{array}{l}\text { Quanto à } \\
\text { recomendaçáo } \\
\text { da obra }\end{array}$ & $\begin{array}{l}\text { Seu colega recomendou a leitura da obra? Para que público? Transcreva } \\
\text { o(s) trecho(s) em que seu colega recomenda a obra, comentando se essa } \\
\text { recomendaçáo parece adequada. }\end{array}$ \\
\hline \multirow{2}{*}{$\begin{array}{l}\text { Quanto aos } \\
\text { aspectos } \\
\text { formais }\end{array}$} & $\begin{array}{l}\text { Há problemas linguísticos (pontuação, frases incompletas, erros ortográficos, } \\
\text { de concordância)? Quais? }\end{array}$ \\
\hline & $\begin{array}{l}\text { A formataçáo está adequada (fonte Times New Roman ou Arial, tamanho 12, } \\
\text { espaçamento } 1,5 \mathrm{~cm} \text { entre as linhas e alinhamento justificado) }\end{array}$ \\
\hline \multirow[t]{2}{*}{$\begin{array}{l}\text { Consideraçóes } \\
\text { gerais }\end{array}$} & $\begin{array}{l}\text { Após ter avaliado o texto de seu colega à luz das questóes acima, você considera } \\
\text { que ele escreveu uma resenha acadêmica ou escreveu outro gênero textual? }\end{array}$ \\
\hline & Há algum outro aspecto que você queira destacar em relação ao texto do colega? \\
\hline
\end{tabular}

Fonte: Das autoras (2019).

\subsection{Aula 6 - Reescrita da resenha e autoavaliaçáo da aprendizagem}

$\mathrm{Na}$ sexta e última aula da sequência, os alunos devem reescrever suas resenhas com base nos conhecimentos construídos a partir do processo de ter avaliado o texto de um colega e nos apontamentos feitos por quem avaliou seu texto. Apenas essa nova versão da resenha acadêmica é avaliada pela professora, recebendo uma nota ${ }^{8}$.

Além da reescrita da primeira versão, os alunos devem realizar uma autoavaliaçáo do processo de aprendizagem da escrita da resenha acadêmica, contemplando os aspectos postos na orientação da atividade:

8 Em geral, as versôes reescritas pelos alunos apresentam o esperado de uma resenha acadêmica. Porém, há casos em que deve ser solicitada uma nova reescrita ao aluno que produziu uma segunda versão do texto muito aquém do mínimo esperado para uma resenha ou que perdeu alguma etapa do processo, o que, pela nossa experiência, compromete o resultado final. 
Quadro 7. Proposta de autoavaliaçáo da aprendizagem, disponibilizada na ferramenta Tarefa

Após fazer as alteraçóes em seu texto, reflita sobre o que você aprendeu em todo esse processo de escrever a resenha acadêmica, avaliar o texto do colega, ter seu texto avaliado e reescrevê-lo. Escreva uma autoavaliação contando sobre como foi esse processo de aprendizagem. O ideal é que, em sua autoavaliação, você comente sobre o que modificou da primeira para a segunda versão do seu texto e por que fez essas modificaçôes, enfatizando o que você aprendeu.

Fonte: Das autoras (2019).

Essa autoavaliaçáo, além de proporcionar que o aluno perceba o que aprendeu ao longo do processo, permite dimensionar os efeitos gerados pelo percurso de ensino do gênero resenha.

\section{Discussáo dos resultados da proposta de abordagem do gênero resenha}

A organização da proposta de trabalho acima descrita buscou promover, em todas as aulas, a interação e o dialogismo (BAKHTIN, 2000), bem como situaçôes de letramento acadêmico (FISHER, 2010; STREET, 2014), que visaram ao desenvolvimento de habilidades e competências para a leitura e a escrita desse gênero. Cabe destacar, porém, que embora a promoção da interação, do dialogismo e do letramento tenha perpassado todas as seis aulas, houve, de acordo com a natureza das atividades propostas, uma ênfase maior ora à interação ora ao letramento.

Nas Aulas 1 e 3, a ênfase recaiu sobre o letramento, já que, ao propor a leitura e a análise de resenhas de obra cultural e de resenhas acadêmicas, respectivamente, buscamos propiciar o letramento acadêmico a partir do contato com exemplares desses tipos de resenha, a discussão da situação de produção e a análise das especificidades de cada um deles. Quanto à interação, foi promovida no momento em que os estudantes foram convidados a postar exemplos de resenhas na ferramenta Fórum, os quais poderiam ser visualizados e comentados por todos.

Já nas Aulas 2, 4, 5 e 6, em que ocorreu a escrita de uma primeira versão da resenha acadêmica, a avaliação do texto produzido por um colega e a reescrita da própria produção textual, o foco foi a interação, tanto entre os colegas (gerada pela atividade de avaliação das produçóes escritas dos colegas, via Laboratório de Avaliação) quanto dos estudantes com seus próprios textos (gerada pela atividade de análise da primeira versão da escrita e posterior reescrita). $\mathrm{O}$ fato de terem sido disponibilizados textos variados para os estudantes resenharem também contribuiu para a promoçáo da interação entre autor da resenha e leitor, dado que o colega avaliador pode ter lido a resenha de um texto por ele desconhecido, sendo ainda mais acentuada a criação de uma situação de produçáo do gênero resenha próxima à realidade (em que as resenhas, ao serem publicadas, cumprem a função de divulgar uma obra a leitores que ainda não entraram em contato com ela).

Essas mesmas atividades proporcionaram situaçóes de letramento, uma vez que os estudantes foram progressivamente se apropriando das habilidades para a 
produçáo proficiente do gênero resenha, por meio da análise dos textos dos colegas e de seus próprios textos a partir dos questionários que deveriam ser respondidos em cada etapa.

O êxito dessa intenção de desenvolver uma proposta de trabalho com o gênero resenha que promovesse a interaçáo fica evidente também nos apontamentos que os estudantes fizeram em suas autoavaliaçóes. Podemos dizer que a maioria se manifestou de forma positiva frente à ideia de interagir com um colega, o que pode ter gerado um esforço maior no sentido de executar a tarefa de forma plena, como se evidencia neste parecer:

Só de pensar que, ao ler uma resenha que eu fiz sobre determinado artigo, eu posso fazer despertar o sentimento e a vontade nas pessoas de quererem ler o artigo original, faz com que este trabalho de fazer a resenha se torne importante para mim.

Muitos alunos relataram, também, a valiosa oportunidade de interagir com o texto do colega, auxiliando-o e sendo auxiliado, o que evidencia a eficácia da avaliação por pares:

Além da escrita, avaliar o colega e de forma anônima é muito interessante, pois possibilita vermos o erro dele e lembrarmos daquilo que pode ser melhorado em nosso trabalho (...) Ter meu texto avaliado é muito importante também, pois me instiga a fazer ajustes em meu trabalho, até mesmo a concordância entre os assuntos, de usar palavras mais adequadas e náo repeti-las tanto e isso é de grande importância para eu poder elaborar a reescrita do meu trabalho.

Alguns estudantes perceberam na avaliação do colega uma outra interpretação para o mesmo texto, além de considerarem positivas as percepçóes dos colegas sobre seu texto, verificando possibilidades de aprimorar sua escrita concretamente. Isso fica evidenciado no depoimento a seguir, em que o estudante relata também ter se apropriado das características do gênero e constatado, como leitor, o impacto de sua escolha discursiva de usar demasiadas vezes as citaçóes diretas:

Achei muito interessante todo o processo do Laboratório de Avaliação, pude ver ao avaliar o texto de um de meus colegas uma visáo bem diferente do mesmo texto, além de aprender um pouco mais na prática, como resumir textos de forma correta. Além disso, com a avaliação que o colega fez do meu texto consegui ver que o meu texto antigo era um tanto chato para se ler, então conforme o conselho do colega troquei algumas citaçóes por paráfrases. A minha maior dificuldade em resumir o texto foi as paráfrases, usei mais citaçóes diretas por medo de não conseguir proporcionar ao leitor a real ideia do autor, porém, ao reler ele várias vezes consegui ver, como leitora, o quanto isso tornou o texto pesado. Acredito que com as mudanças que fiz o texto ficou bem mais atrativo.

O material didático disponibilizado como auxiliar na execução da tarefa também foi apontado como relevante no processo. Este aluno explica que percebeu, durante a avaliaçáo do texto do colega, e em funçáo da questão proposta para avaliação, que era necessário apresentar a obra e o capítulo resenhado: 
Neste processo de elaboração de resenha acadêmica, busquei informaçôes nos materiais disponibilizados e muito nas resenhas apresentadas como exemplo. Achei de extrema importância a etapa de avaliação da resenha do colega, ainda mais na forma de perguntas, pois foi através deste exercício que comecei a pensar se havia feito minha resenha de acordo com as perguntas que eu estava respondendo para avaliação do colega. Realizei mudanças em relação a informação da obra toda, pois me contive apenas no capitulo indicado, e vi que uma das perguntas na hora da avaliação da resenha do colega era se havia informaçóes sobre a obra, ou apenas sobre o tema.

A fala a seguir demonstra que o estudante refletiu sobre o objetivo da escrita de uma resenha para além de recomendar a leitura de uma determinada obra, mas também como forma de estudar um texto (o que indica a relevância de os estudantes universitários aprenderem a escrever resenhas):

Esse processo de escrever uma resenha, avaliar o texto de um colega e ter o meu avaliado foi engrandecedor.

As sugestôes feitas pelo colega contribuíram para que a qualidade do meu texto melhorasse, principalmente em relação à pontuação adequada e a substituição de algumas palavras que se repetiram ao longo do texto. Aprendi que na resenha, é necessário apresentar, descrever, avaliar e recomendar a obra, sendo que a avaliação é a parte mais importante desse gênero textual. A resenha funciona tanto como uma complementação da leitura do próprio livro, como um meio de recomendação para quem ainda náo o leu.

O depoimento a seguir demonstra que o aluno percebeu avanços no processo de escrita do gênero resenha, apresentando uma facilidade maior ao lidar com textos dessa natureza, inclusive em outros componentes curriculares:

Com a disciplina, aprendi a escrever uma resenha. Como falei em outra avaliação, eu não sabia escrever, mas com o tempo eu fui pegando o jeito e acredito que melhorei muito desde a primeira atividade, depois que fiz as resenhas, outras disciplinas tiveram essa atividade, e fui bem, pois já sabia escrever. Gostei do que o colega falou, pois me senti mais confiante e ele fez bem em dizer que tive alguns erros de acentuação, pois não tinha visto. Ter comentado o texto de outro colega é uma responsabilidade, mas como senti mais confiança em fazer a minha resenha, desta vez foi mais fácil avaliar o do colega. Adorei essa disciplina, aprendi muito, o que náo tinha aprendido no ensino médio e vou levar esse aprendizado pro resto da vida.

Como é possível depreender nos comentários dos estudantes, a sequência proposta para o ensino do gênero resenha aponta caminhos para se pensar em formas de ensinar e aprender que propiciem a interaçáo e o letramento a partir da disponibilização de materiais diversos e do uso pedagógico de ferramentas tecnológicas. Mostrou-se especialmente relevante que o texto tenha um leitor que náo seja apenas o professor e que avaliar o texto de um colega, mesmo que não implique atribuição de nota, é tarefa que precisa ser realizada com grande responsabilidade e gera aprendizados significativos. 


\section{Consideraçóes finais}

Essa proposta tem se mostrado efetiva, sobretudo por três aspectos essenciais para a escrita da resenha. O primeiro é o contato que os estudantes têm com resenhas autênticas, ora selecionadas pelos professores, ora por eles mesmos, porque com isso identificam as características estruturais e discursivas do gênero. Outro aspecto é a interação com os textos produzidos pelos colegas, que permite um aprofundamento dos conhecimentos sobre o gênero - já que para avaliar o texto do colega, o estudante precisa ter se apropriado das características da resenha - e possibilita aos discentes poder fazer uma análise crítica do próprio texto, o que qualifica também a segunda versão. Por fim, a reflexão, reescrita e autoavaliação permitem uma tomada de consciência sobre o processo de escrita do gênero.

Nesse sentido, pudemos observar que, em nossa sequência de aulas, o uso em profusão de roteiros para auxiliar os alunos no desenvolvimento de suas tarefas foi uma escolha acertada - como atestam as autoavaliaçóes dos estudantes -, tendo em vista que esses roteiros foram pensados para guiar o aluno naquilo a que ele precisa atentar tanto na leitura quanto na escrita. Sendo assim, essa constataçáo pode ser evidência de que é um equívoco pressupor que o aluno sempre tem condições para, de forma autônoma, desenvolver a contento determinada tarefa de leitura ou de escrita.

Por fim, entendemos que a sequência que desenvolvemos para abordar o gênero resenha não se restringe ao ensino a distância, já que as atividades propostas poderiam ser realizadas em aula presencial ou pelos alunos de forma independente. Embora as ferramentas do Moodle que mobilizamos tenham se mostrado bastante profícuas no desenvolvimento do percurso de ensino, é preciso ter claro que "não são as tecnologias que vão revolucionar o ensino e, por extensão, a educação de forma geral, mas a maneira como essa tecnologia é utilizada para a mediação entre professores, alunos e a informação" (KENSKI, 2003, p. 121). Assim, o essencial é que haja interação, diálogo entre os colegas, entre professores e estudantes, mediados por tecnologias digitais ou não, posto que é nesse processo contínuo e coparticipativo de ensino e aprendizagem que se produzem conhecimentos relevantes e duradouros.

O que propomos neste trabalho não se esgota no desenvolvimento de práticas pedagógicas. $\mathrm{O}$ caminho passa também por investigar como está sendo abordado o ensino da escrita acadêmica não apenas em componentes curriculares comuns a todos os cursos de graduação, mas também nos componentes específicos. É a isso que se propóe o projeto de pesquisa em andamento na Univates - $O$ ensino de escrita acadêmica em cursos de graduaçáo na Universidade do Vale do Taquari cujo objetivo é investigar quais são as concepçóes de ensino de escrita acadêmica em planos de ensino de componentes ministrados em cursos de graduaçáo dessa instituição. Os resultados desse estudo podem servir para estabelecer diálogo com projetos de pesquisa de outras instituiçóes de ensino superior que se propóem a investigar o ensino de escrita acadêmica, bem como para desenvolver estratégias que possibilitem aprimorar e tornar mais significativos o ensino e a aprendizagem de gêneros acadêmicos. 


\section{Referências}

ANTUNES, Irandé. Aula de português: encontro \& interação. 8. ed. São Paulo: Parábola Editorial, 2003.

BAKHTIN, Mikhail. Estética da criaçáo verbal. Tradução: PEREIRA, M. E. G. São Paulo: Martins Fontes, 2000.

CAZAROTO, Cláudia. A interação a distância: recursos textuais empregados em EAD. In: CELLI - COLÓQUIO DE ESTUDOS LINGUÍSTICOS E LITERÁRIOS. 3, 2007, Maringá. Anais do CELLI. Maringá, 2009, p. 1257-1266.

FISCHER, A. Os usos da língua na construção de sujeitos letrados: relaçóes entre a esfera escolar e a acadêmica. Acta Scientiarum. Language and Culture, v. 32, n. 2, p. 215-224, 2010.

KENSKI, Vani Moreira. Tecnologias e ensino presencial e a distância. Campinas, SP: Papirus, 2003.

MACHADO, Anna Rachel. Resenha. São Paulo: Parábola Editorial, 2004.

MARCUSCHI, Luiz Antônio. Produçáo textual, análise de gêneros e compreensão. São Paulo: Parábola Editorial, 2008.

MARINHO, Marildes. A escrita nas práticas de letramento acadêmico. RBLA, Belo Horizonte, v. 10, n. 2, p. 363-386, 2010.

MAZUR, E. Peer Instruction: a revolução da aprendizagem ativa. Porto Alegre: Penso, 2015.

MOTTA-ROTH, Désirée; HENDGES, Graciela Rabuske. Produção Textual na universidade. São Paulo: Parábola Editorial, 2010.

STREET, Brian. Letramentos Sociais: abordagens críticas do letramento no desenvolvimento, na etnografia e na educação. São Paulo: Parábola Editorial, 2014.

TRAVAGLIA, Luiz Carlos. Competência comunicativa. In: FRADE, Isabel C. Alves da Silva et al. Glossário Ceale: termos de alfabetizaçáo, leitura e escrita para educadores. Belo Horizonte: UFMG/Faculdade de Educação, 2014. Disponível em: http://ceale. fae.ufmg.br/app/webroot/glossarioceale/verbetes/competencia-comunicativa. Acesso em 23/04/2020. 